\title{
ANALISIS RISIKO KESELAMATAN DAN KESEHATAN KERJA DENGAN METODE HAZOP DAN PENDEKATAN ERGONOMI (STUDI KASUS: UD. BAROKAH BANTUL)
}

\author{
Iva Mindhayani \\ Fakultas Teknik, Program Studi Teknik Industri \\ Universitas Widya Mataram \\ Email: ivamindhayani@gmail.com
}

\begin{abstract}
ABSTRAK
UD. Barokah merupakan perusahaan yang memproduksi kerupuk. Dalam menjalankan produksinya tentu ada proses produksi yang memiliki potensi bahaya (hazard). Potensi bahaya apabila tidak dikendalikan dengan baik ada kemungkinan potensi bahaya yang ada bisa beresiko menyebabkan terjadinya kelelahan, keluhan muskuloskeletal, resiko cedera bahkan kecelakaan kerja. Tujuan Penelitian ini adalah untuk membantu UD. Barokah melakukan identifikasi hazard terhadap keselamatan dan kesehatan kerja (K3) yang terjadi, sehingga dapat dilakukan pengendalian dan pencegahan terhadap bahaya yang muncul di area kerja. Untuk mengetahui adanya hazard dari segi ergonomi digunakan kusioner NBM dan QEC, sedangkan untuk identifikasi hazard yang ada dengan menggunakan metode HAZOP. Hasil analisis potensi bahaya diketahui bahwa sumber bahaya yang dapat atau berpotensi menimbulkan kecelakaan kerja adalah sikap pekerja, kondisi lingkungan kerja fisik, lantai licin karena adanya tumpahan tepung terigu dan adonan bahan pembuatan kerupuk. Selain itu, diketahui bahwa terdapat resiko ergonomi yang dalam pekerjaan proses pembuatan kerupuk. Resiko yang dialami berupa gangguan muskuloskeletal dan kelelahan yang muncul pada bagian, pinggang, lengan, pergelangan tangan, betis dan pergelangan kaki.
\end{abstract}

Kata kunci: hazard; ergonomic; HAZOP; NBM; QEC.

\section{ABSTRACT}

UD. Barokah is a company that produces crackers. In carrying out its production, there is certainly a production process that has potential hazards. Potential hazards if not controlled properly there is the possibility of potential hazards that can be at risk of causing fatigue, musculoskeletal complaints, the risk of injury and even work accidents. The purpose of this study was to help UD. Barokah identifies hazards to occupational safety and health (K3) that occur, so that control and prevention can be carried out against hazards that arise in the workplace. To find out the presence of potential hazards in terms of ergonomics, it was used to determine the NBM and QEC, while to identify the hazards that existed by using the HAZOP method. The results of the analysis of potential hazards are known that the source of danger that can or has the potential to cause workplace accidents is the attitude of workers, physical work environment conditions, slippery floors due to spills of flour and ingredients of crackers. In addition, it is known that there are ergonomic risks in the work of making crackers. The risks involved are musculoskeletal and fatigue disorders that appear on the part, waist, arms, wrists, calves and ankles.

Keywords: Hazard; ergonomics; HAZOP; NBM; QEC.

\section{PENDAHULUAN}

Setiap pekerjaan memiliki potensi bahaya (hazard). Apabila potensi bahaya tidak diperhatikan dan dikendalikan, bisa berpotensi menyebabkan terjadinya kelelahan, keluhan muskulosekeletal, cedera, bahkan mungkin terjadi kecelakaan kerja. Maka dari itu perlu dilakukan pengendalian bahaya dengan menemukan potensi bahaya yang ada pada area kerja, lalu dilakukan identifikasi bahaya.

Selanjutnya setelah berhasil melakukan identifikasi sumber bahaya yang ada, maka perlu dievaluasi tingkat resikonya terhadap para pekerja. Dengan begitu hal-hal yang tidak diharapkan dari peristiwa kecelakaan kerja bisa dicegah. Untuk perlu keterlibatan semua pihak mulai dari pimpinan sampai dengan pekerja paling bawah untuk turut berpartisipasi dalam penerapan keselamatan dan kesehatan kerja di tempat kerja. Budaya keselamatan yang menjadi dasar adalah sikap dan persepsi pekerja terhadap keselamatan kerja, yang nantinya menjadi salah satu gambaran perilaku pekerja terhadap pelaksanaan peraturan dan prosedur $\mathrm{K} 3$ dalam rangka mengendalikan sumber potensi bahaya [5]. 
UD. Barokah merupakan industri rumah tangga yang memproduksi kerupuk seperti; kerupuk rambak, kerupuk mawar. UD. Barokah sudah memproduksi aneka kerupuk selama bertahun-tahun. Agar bisa tetap bertahan dan mampu bersaing dengan produsen kerupuk yang lain, maka UD. Barokah harus mampu meningkatkan kualitas dan menekan biaya salah satunya dengan cara menerapkan K3 dalam produksi. Dengan begitu diharapkan pekerja dapat bekerja dengan aman, nyaman dan selamat sehingga produktivitas pekerja tetap terjaga.

Hasil studi pendahuluan dengan pengamatan langsung ke lapangan dapat diketahui bahwa UD. Barokah belum menerapkan manajemen K3 dengan baik. Berdasarkan informasi dari pemilik, pernah terjadi beberapa kali kecelakaan kerja yaitu tangan terbakar saat menghidupkan kompor penggorengan. Selain itu, pekerja yang bekerja dengan posisi yang canggung, tidak ergonomis dan berulang-ulang bisa berpotensi menyebabkan kelelahan dan keluhan muskuloskeletal seperti pada tahap pembuburan, tahap pencetakan kerupuk dan tahap penggorengan. Potensi-potensi bahaya yang ada tidak mereka sadari yang mana bisa mengakibatkan terjadinya kecelakaan kerja dan penyakit akibat kerja. Adanya resiko ergonomi pada proses pembuatan kerupuk perlu dianalisis dengan pendekatan ergonomi. Menurut [3] menyatakan bahwa risiko ergonomi ini disebabkan oleh kesalahan postur manusia saat bekerja.

Berdasarkan latar belakang tersebut perlu dilakukan analisis mengenai potensi bahaya (hazard) yang ada dalam proses produksi yang beresiko terhadap Keselamatan dan Kesehatan Kerja di UD. Barokah. Identifikasi potensi bahaya merupakan suatu cara untuk menemukan situasi yang mana sumber energi yang digunakan di tenpat kerja tanpa dadanya pengendalian yang memadai [6]. Analisis potensi bahaya dilakukan dengan menggunakan teknik HAZOP dan konsep ergonomi.

\section{METODOLOGI PENELITIAN}

Penelitian ini merupakan penelitian deskriptif karena menggambarkan keadaan objek dengan analisis kualitatif tanpa pengujian hipotesis. Penelitian ini berhubungan dengan perbaikan penerapan keselamatan dan kesehatan kerja (K3) di UD. Barokah Bantul dengan pendekatan Hazard and Operability Study (HAZOP) dan ergonomi. Untuk analisis dengan menggunakan pendekatan ergonomi, peneliti menggunakan dua kusioner yaitu Nordic Body Map (NBM) dan Quick Exposure Checklist (QEC). Tahapan penelitian yang akan dilakukan meliputi beberapa tahapan sebagai berikut:

\subsection{Tahap Studi Pendahuluan}

Studi pendahuluan berupa studi lapangan dan studi literatur untuk mendapatkan gambaran mengenai permasalahan yang ada.

\subsection{Tahap pengumpulan dan pengolahan data [4]:}

a. Mengetahui urutan proses yang ada pada proses produksi

b. Mengidentifikasi adanya potensi bahaya pada area kerja dengan mengamati adanya segala penyimpangan yang terjadi sehingga mampu menyebabkan kecelakaan kerja dilakukan dengan cara observasi lapangan secara langsung.

c. Melengkapi kriteria yang ada pada HAZOP worksheet seperti pada Tabel 1 dan Tabel 2 dengan urutan sebagai berikut:

1. Mengklasifikasikan hazard yang diketemukan (sumber hazard dan frekuensi temuan hazard).

2. Mendeskripsikan deviation atau penyimpangan yang terjadi selama proses operasi

3. Mendeskripsikan penyebab terjadinya penyimpangan (cause)

4. Mendeskripsikan apa yang dapat ditimbulkan dari penyimpangan tersebut (consequences).

5. Menentukan action atau tindakan sementara yang dapat dilakukan.

Tabel 1. Kriteria likelihood

\begin{tabular}{|c|c|c|c|}
\hline \multicolumn{4}{|c|}{ Likelihood } \\
\hline \multirow[t]{2}{*}{ Level } & \multirow[t]{2}{*}{ Criteria } & \multicolumn{2}{|l|}{ Description } \\
\hline & & Kualitatif & Kuantitatif \\
\hline 1 & Jarang terjadi & $\begin{array}{l}\text { Dapat dipikirkan tetapi tidak hanya saat } \\
\text { keadaan yang ekstrim }\end{array}$ & $\begin{array}{l}\text { Kurang dari } 1 \text { kali per } 10 \\
\text { tahun }\end{array}$ \\
\hline 2 & Kemungkinan kecil & $\begin{array}{l}\text { Belum terjadi tetapi bisa muncul / } \\
\text { terjadi pada suatu waktu }\end{array}$ & $\begin{array}{l}\text { Terjadi } 1 \text { kali per } 10 \\
\text { tahun }\end{array}$ \\
\hline 3 & Mungkin & $\begin{array}{l}\text { Seharusnya terjadi dan mungkin telah } \\
\text { terjadi / muncul disini atau di tempat }\end{array}$ & $\begin{array}{l}1 \text { kali per } 5 \text { tahun sampai } \\
1 \text { kali per tahun }\end{array}$ \\
\hline
\end{tabular}




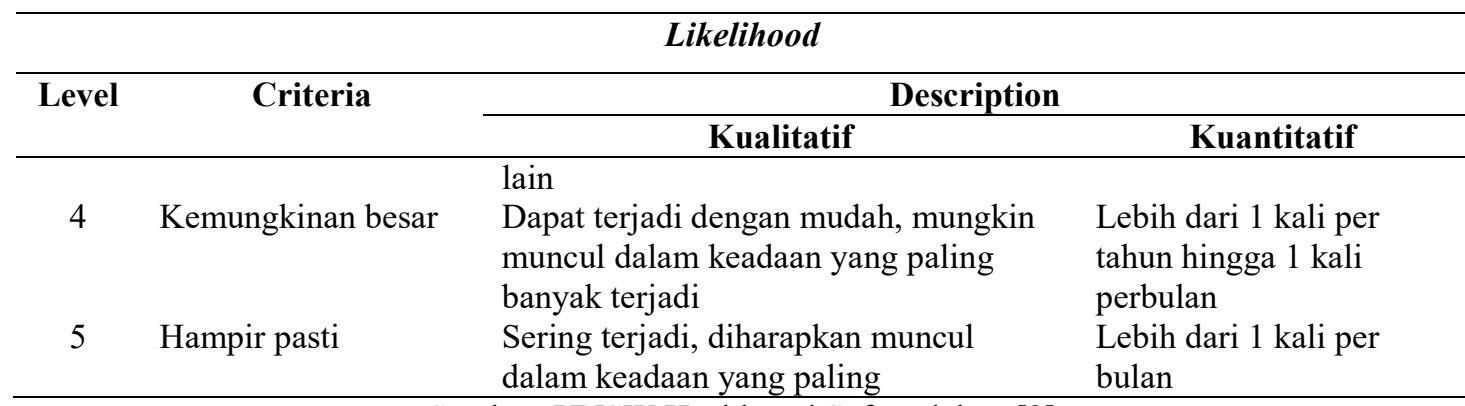

Sumber: UNSW Health and Safety dalam [2]

Kriteria likelihood merupakan salah satu kriteria yang digunakan dalam menilai resiko. Kriteria likelihood (seperti pada Tabel 1) yang digunakan adalah frekuensi dalam perhitungannya secara kuantitatif berdasarkan data atau record perusahaan selama kurun waktu tertentu. Dalam Tabel 1 kriteria likelihood memiliki tingkatan level 1 sampai 5, serta terdapat lima kriteria yaitu: level 1 memiliki kriteria jarang terjadi, level 2 memiliki kriteria kemungkinan kecil, level 3 memiliki kriteria mungkin, level 4 memiliki kriteria kemungkinan besar dan level 5 memiliki kriteria hamper pasti.

Tabel 2. Kriteria consequences/severity

\begin{tabular}{|c|c|c|c|}
\hline \multicolumn{4}{|c|}{ Consequences/Severity } \\
\hline Level & Uraian & Keparahan Cidera & Hari Kerja \\
\hline 1 & $\begin{array}{l}\text { Tidak } \\
\text { signifikan }\end{array}$ & $\begin{array}{l}\text { Kejadian tidak menimbulkan kerugian } \\
\text { atau cedera pada manusia }\end{array}$ & $\begin{array}{l}\text { Tidak menyebabkan } \\
\text { kehilangan hari kerja }\end{array}$ \\
\hline 2 & Kecil & $\begin{array}{l}\text { Menimbulkan cedera ringan, kerugian } \\
\text { kecildan tidak menimbulkan dampak } \\
\text { serius terhadap kelangsungan bisnis }\end{array}$ & $\begin{array}{l}\text { Masih dapat bekerja } \\
\text { pada hari / shift yang } \\
\text { sama }\end{array}$ \\
\hline 3 & Sedang & $\begin{array}{l}\text { Cedera berat dan dirawat dirumah } \\
\text { sakit, tidak menimbulkan cacat tetap, } \\
\text { kerugian finansial sedang }\end{array}$ & $\begin{array}{l}\text { Kehilangan hari kerja } \\
\text { dibawah } 3 \text { hari }\end{array}$ \\
\hline 4 & Berat & $\begin{array}{l}\text { Menimbulkan cedera parah dan cacat } \\
\text { tetap dan kerugian finansial besar serta } \\
\text { menimbulkan dampak serius terhadap } \\
\text { kelangsungan usaha }\end{array}$ & $\begin{array}{l}\text { Kehilangan hari kerja } \\
3 \text { hari atau lebih }\end{array}$ \\
\hline 5 & Bencana & $\begin{array}{l}\text { Mengakibatkan korban meninggal dan } \\
\text { kerugian parah bahkan dapat } \\
\text { menghentikan kegiatan usaha } \\
\text { selamanya }\end{array}$ & $\begin{array}{l}\text { Kehilangan hari kerja } \\
\text { selamanya }\end{array}$ \\
\hline
\end{tabular}

Sumber: UNSW Health and Safety dalam [2]

Kriteria consequences (severity) yang digunakan adalah akibat apa yang akan diterima pekerja yang didefinisikan secara kualitatif serta mempertimbangkan hari kerja yang hilang (seperti pada Tabel 2). Kriteria consequences juga sama seperti kriteria likelihood yang memiliki skalal sampai 5 ,

6. Menilai risiko (risk assessment) yang timbul dengan mendefinisikan kriteria likelihood dan consequences (severity).

7. Melakukan perangkingan dari hazard yang telah diidentifikasi menggunakan worksheet HAZOP dengan memperhitungkan likelihood dan consequence, kemudian menggunakan risk matrix (seperti pada Gambar 1) untuk mengetahui prioritas hazard yang harus diberi prioritas untuk diperbaiki. 


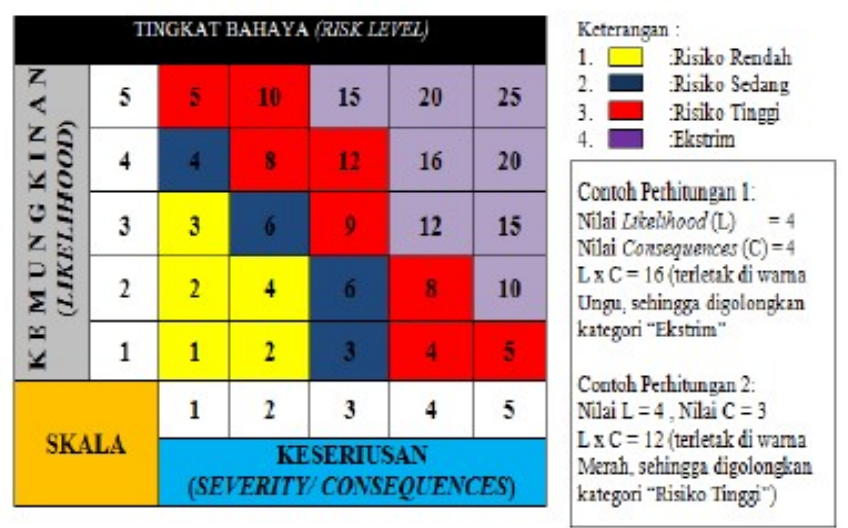

Gambar 1. Risk Matrix

Sumber: UNSW Health and Safety dalam [2]

Risk matrix atau matrik resiko merupakan sebuah matrik yang menggambarkan hasil perkalian antara kemungkinan (likelihood) dan keseriusan (consequences). Dimana likelihood dan consequences memiliki tingkatan skala 1 sampai 5 sesuai dengan Tabel 1 dan Tabel 2. Tingkat bahaya yang merupakan hasil perkalian digambarkan dengan 4 warna yang menandakan tingkat resiko yaitu: 1) warna kuning berarti memiliki resiko rendah, 2) warna biru memiliki resiko sedang, 3) warna merah memiliki resiko tinggi, 4) warna ungu memiliki resiko ekstrim.

8. Identifikasi resiko dari kondisi kerja bagian produksi kerupuk dengan menyebarkan kuisioner NBM dan QEC.

9. Mengolah data Nordic Body Map (NBM) dan Quick Exposure Checklist (QEC) untuk mendapatkan skor keluhan pada bagian tubuh para pekerja.

Tabel 3. Skor hasil quick exposure checklist (QEC)

\begin{tabular}{ccl}
\hline Jumlah Skor & Action Level & \multicolumn{1}{c}{ Penanganan } \\
\hline Kurang dari 70 & 1 & $\begin{array}{l}\text { Nilai dapat diterima } \\
\text { Perlu investigasi lebih lanjut }\end{array}$ \\
$70-88$ & 2 & $\begin{array}{l}\text { Perlu investigasi lebih lanjut dan dilakukan } \\
\text { penanganan dalam waktu dekat }\end{array}$ \\
$89-123$ & 3 & $\begin{array}{l}\text { Perlu investigasi lebih lanjut dan dilakukan } \\
\text { penanganan secepatnya }\end{array}$ \\
lebih dari 123 & 4 & Sumber : [1]
\end{tabular}

Skor hasil QEC seperti ditunjukkan pada Tabel 3 sebagai acuan dalam menentukan action level. Total skor yang dihasilkan pada lembar ceklist diisi oleh pekerja dan kepala bagian produksi selanjutnya dilihat pada tabel tersebut total skor yang dihasilkan masuk action level berapa sehingga penanganan diharapkan bisa tepat dan sesuai. Action level terdiri dari level 1 sampai dengan level 4 dengan batas skor yang telah ditentukan.

\subsection{Tahap Analisis dan Pembahasan}

Pada tahap ini menjabarkan sumber-sumber dan akar penyebab dari permasalahan yang mengakibatkan kecelakaan kerja maupun gangguan proses itu terjadi serta menjabarkan hasil kuisioner.

\subsection{Kesimpulan dan Saran}

Tahap terakhir yaitu menyimpulkan hasil analisis dan memberikan saran atau rekomendasi perbaikan proses untuk mengurangi bahkan menghilangkan bahaya yang berpotensi menyebabkan terjadinya kecelakaan kerja.

\section{HASIL DAN PEMBAHASAN}

Untuk mengidentifikasi adanya potensi bahaya apa saja yang ada pada proses produksi maka perlu dilakukan pengamatan langsung dan mengetahui alur proses produksinya. Berikut tahapan proses pembuatan kerupuk: 
a. Proses mbubur

Proses mbubur merupakan proses pembuatan adonan dengan mencampurkan bahan-bahan yang dibutuhkan. Pada proses ini bahan-bahan antara lain: bumbu yang telah diblender yang terdiri dari bawang putih dan garam dicampur dengan tepung tapioka lalu diberi air panas kemudian diadukaduk sekitar 10 - 15 menit. Proses mbubur biasanya dilakukan pada sore hari dan didiamkan selama satu malam sehingga paginya baru bisa di proses lebih lanjut.

b. Proses molen

Merupakan proses pengadukan bahan yang telah melalui proses pembuburan dimasukkan dalam mesin molen dan diberi tepung tapioka lagi dengan tujuan membuat adonan menjadi kalis atau adonan tidak lengket sehingga bisa dicetak. Pada proses ini membutuhkan waktu sekitar 15 menit.

c. Proses pencetakan

Pada proses pencetakan adonan yang sudah kalis kemudian dipindahkan ke mesin pencetak. Mesin pencetak kerupuk mawar membutuhkan setup waktu kurang lebih 3 menit.

d. Proses langsengan

Merupakan proses pengovenan. Dimana kerupuk yang telah dicetak diletakkan pada anjang yang terbuat dari bambu kemudian ditumpuk dan dimasukkan dalam ruangan oven dengan temperatur $100^{\circ} \mathrm{C}$ sehingga kerupuk matang. Waktu yang dibutuhkan pada proses langsengan sekitar $7-10$ menit. Dalam satu ruang oven berisi 20 anjang yang ditumpuk. Jadi pada proses langsengan ini seperti proses mengkukus. Maka dari itu proses langsengan biasa disebut juga sebagai proses oven basah.

e. Proses oven kering

Setelah kerupuk melalui proses oven basah kemudian dimasukkan dalam ruang pengering (oven kering) selama kurang lebih 3 jam. Tujuan proses oven kering adalah agar kerupuk menjadi kering. Luas ruang oven 5 x 8 meter dengan tekanan maksimal $4 \mathrm{~kg} / \mathrm{cm}$.

f. Proses penjemuran

Merupakan proses penjemuran kerupuk mawar dibawah terik matahari. Sebenarnya kerupuk mawar yang telah melalui proses oven kering ada yang kondisinya sudah kering ada yang masih kurang kering. Proses penjemuran di luar ruangan dibawah terik matahari dilakukan untuk kerupuk yang kondisinya kurang kering. Waktu yang dibutuhkan pada proses penjemuran sekitar $1 / 2$ hari.

g. Proses penggorengan

Proses penggorengan kerupuk mawar tidak dilakukan setiap hari. Biasanya dalam seminggu 2-3 kali goreng.

Setelah mengetahui urutan proses produksi, selanjutnya dilakukan pengamatan langsung ke lapangan dan melakukan wawancara dengan pemilik usaha. Hasil temuan hazard atau potensi bahaya yang ada selanjutnya menghitung skor resiko seperti terlihat pada Tabel 3.

Tabel 3. Skor level temuan potensi bahaya

\begin{tabular}{|c|c|c|c|c|c|c|c|c|}
\hline No & Proses & Temuan Hazard & Resiko & Sumber Hazard & $\mathbf{L}$ & $\mathbf{C}$ & $\mathbf{S}$ & $\begin{array}{l}\text { Risk } \\
\text { level }\end{array}$ \\
\hline \multirow[t]{5}{*}{1} & Mbubur & $\begin{array}{l}\text { lantai licin karena } \\
\text { adanya tepung terigu, } \\
\text { adonan pembuburan } \\
\text { kerupuk yang } \\
\text { berceceran }\end{array}$ & Jatuh terpeleset & $\begin{array}{l}\text { Tumpahan tepung } \\
\text { terigu dan adonan } \\
\text { yang bercecer di } \\
\text { lantai }\end{array}$ & 2 & 2 & 4 & Rendah \\
\hline & & $\begin{array}{l}\text { Posisi kerja tidak } \\
\text { ergonomis } \\
\text { (membungkuk) dan } \\
\text { gerakan berulang }\end{array}$ & $\begin{array}{l}\text { Keluhan } \\
\text { muskuloskeletal }\end{array}$ & Sikap pekerja & 4 & 2 & 8 & Tinggi \\
\hline & & Area kerja bising & Ketulian & $\begin{array}{l}\text { Kondisi lingkungan } \\
\text { kerja fisik }\end{array}$ & 4 & 1 & 4 & Sedang \\
\hline & & Ruang produksi panas & $\begin{array}{l}\text { Tidak nyaman } \\
\text { dan mudah } \\
\text { merasa lelah }\end{array}$ & $\begin{array}{l}\text { Kondisi lingkungan } \\
\text { kerja fisik }\end{array}$ & 5 & 1 & 5 & Tinggi \\
\hline & & $\begin{array}{l}\text { Tidak menggunakan } \\
\text { APD (masker) }\end{array}$ & Sesak napas & Sikap pekerja & 2 & 1 & 2 & Rendah \\
\hline 2 & $\begin{array}{l}\text { Molen } \\
\text { (Pengad } \\
\text { ukan) }\end{array}$ & $\begin{array}{l}\text { lantai licin karena } \\
\text { adanya tepung terigu, } \\
\text { adonan pembuburan }\end{array}$ & jatuh terpeleset & $\begin{array}{l}\text { Tumpahan tepung } \\
\text { terigu dan adonan } \\
\text { yang bercecer di }\end{array}$ & 2 & 2 & 4 & Rendah \\
\hline
\end{tabular}




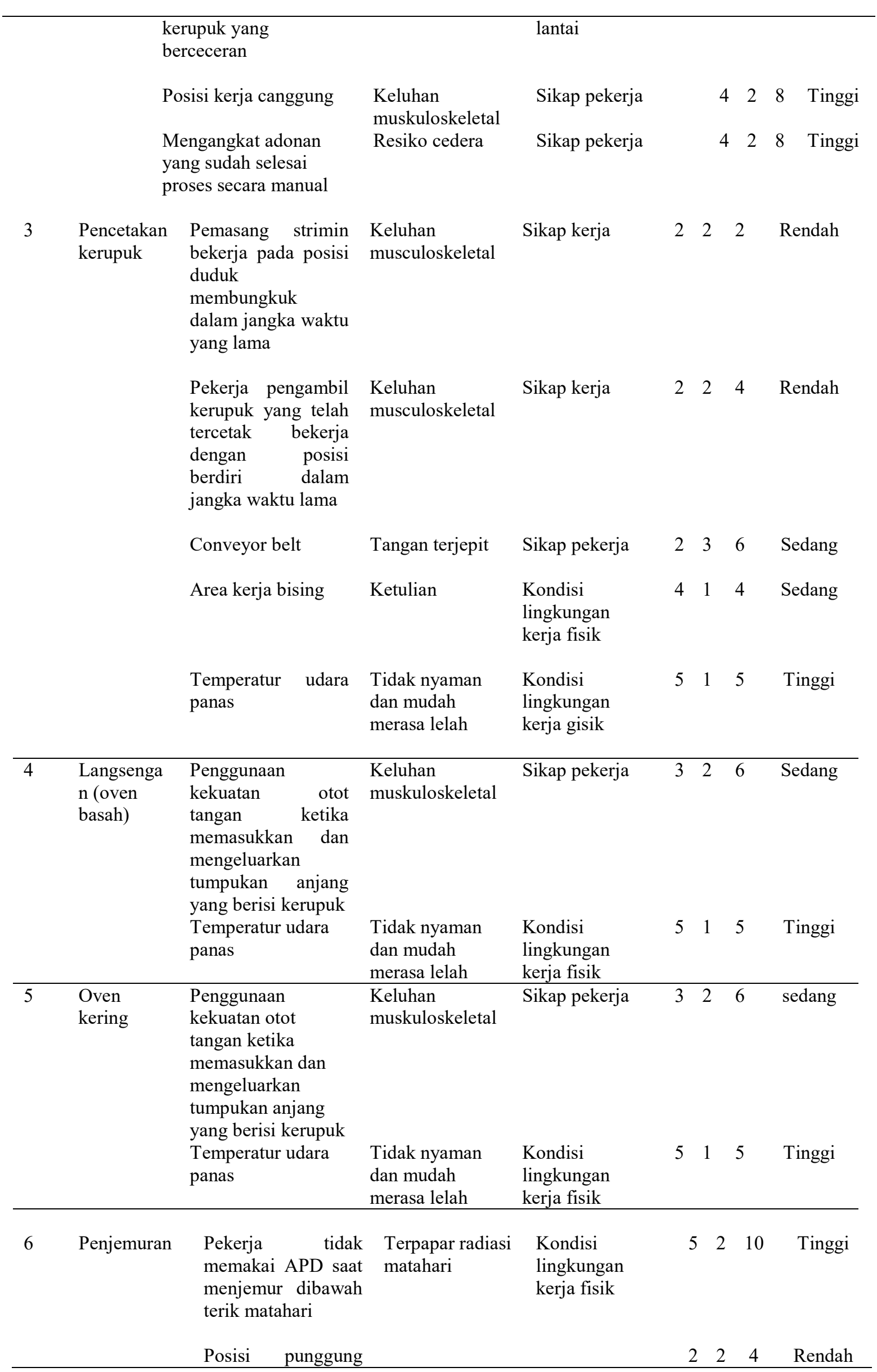




\begin{tabular}{|c|c|c|c|c|c|c|c|c|}
\hline & & $\begin{array}{l}\text { membungkuk } \\
\text { ketika menjemur } \\
\text { kerupuk }\end{array}$ & $\begin{array}{l}\text { Keluhan } \\
\text { muskuloskeletal }\end{array}$ & Sikap pekerja & & & & \\
\hline \multirow[t]{7}{*}{7} & \multirow[t]{7}{*}{$\begin{array}{l}\text { Penggorenga } \\
\mathrm{n}\end{array}$} & $\begin{array}{lr}\text { Lantai masih tanah } \\
\text { dan } & \text { adanya } \\
\text { tumpahan } & \text { minyak } \\
\text { goreng } & \end{array}$ & Jatuh terpeleset & $\begin{array}{l}\text { Kondisi } \\
\text { lingkungan } \\
\text { kerja }\end{array}$ & 2 & 2 & 4 & Rendah \\
\hline & & $\begin{array}{l}\text { Sirkulasi udara } \\
\text { kurang }\end{array}$ & $\begin{array}{l}\text { Ketidaknyaman } \\
\text { an pekerja }\end{array}$ & $\begin{array}{l}\text { Kondisi } \\
\text { lingkungan } \\
\text { keria fisik }\end{array}$ & 3 & 2 & 6 & Sedang \\
\hline & & $\begin{array}{l}\text { Temperatur udara } \\
\text { panas }\end{array}$ & $\begin{array}{l}\text { Ketidaknyaman } \\
\text { an pekerja }\end{array}$ & $\begin{array}{l}\text { Kondisi } \\
\text { lingkungan } \\
\text { kerja fisik }\end{array}$ & 5 & 1 & 5 & Tinggi \\
\hline & & $\begin{array}{l}\text { Berdiri dalam } \\
\text { jangka waktu lama } \\
\text { saat menggoreng }\end{array}$ & $\begin{array}{l}\text { Keluhan } \\
\text { muskuloskeletal }\end{array}$ & Sikap pekerja & 4 & 2 & 8 & Tinggi \\
\hline & & $\begin{array}{l}\text { Punggung memutar } \\
\text { dan membungkuk } \\
\text { ketika mengambil } \\
\text { kerupuk metah } \\
\text { untuk dimasukkan } \\
\text { ke penggorengan }\end{array}$ & $\begin{array}{l}\text { Keluhan } \\
\text { muskuloskeletal }\end{array}$ & Sikap pekerja & 2 & 1 & 2 & Rendah \\
\hline & & $\begin{array}{l}\text { Mengangkat kerupuk } \\
\text { yang telah digoreng } \\
\text { secara manual }\end{array}$ & $\begin{array}{l}\text { Keluhan } \\
\text { muskuloskeletal }\end{array}$ & Sikap pekerja & 4 & 2 & 8 & Tinggi \\
\hline & & $\begin{array}{l}\text { Pekerja tidak } \\
\text { menggunakan APD }\end{array}$ & $\begin{array}{l}\text { Tersiram / } \\
\text { terkena minyak } \\
\text { goreng panas }\end{array}$ & Sikap pekerja & 4 & 2 & 8 & Tinggi \\
\hline
\end{tabular}

Berdasar hasil perhitungan skor resiko yang dapat dilihat pada Tabel 3 dapat diketahui bahaya yang ditimbulkan pada proses pembuatan kerupuk antara lain:

a. Resiko tinggi, terdapat pada semua area kerja dengan uraian resiko seperti keluhan muskuloskeletal, ketidaknyamanan pekerja, resiko cedera, terpapar radiasi sinar matahari dan terkena minyak goreng panas.

b. Resiko sedang, terdapat pada semua area kerja dengan uraian resiko seperti keluhan muskuloskeletal, ketidaknyamanan pekerja, ketulian, tangan terjepit.

c. Resiko rendah, terdapat pada semua area kerja dengan uraian seperti jatuh terpeleset, sesak nafas dan keluhan muskuloskeletal.

Pada semua proses produksi memiliki potensi bahaya yang mana dampaknya tidak langsung terlihat dalam waktu singkat tapi beberapa waktu mendatang kalau potensi bahaya yang ada tidak segera dilakukan tindakan perbaikan. Selain analisa identifikasi bahaya dengan metode HAZOP juga dilakukan analisis dengan pendekatan ergonomi yaitu dengan menyebarkan kuisioner NBM dan QEC. Pekerja yang berjumlah 19 orang diminta untuk mengisi kuisioner, dimana sebelum mengisi kuisioner pekerja diwawancara terlebih dahulu apakah sebelum mulai bekerja ada keluhan-keluhan pada anggota tubuh sesuai dengan petunjuk yang ada pada kuisioner NBM. Seluruh responden dalam hal ini pekerja menyatakan tidak merasakan sakit pada anggota tubuh sebelum mulai bekerja. Selanjutnya setelah $4-5$ jam bekerja responden diminta mengisi kusioner NBM. Kusioner NBM digunakan untuk mengetahui ada atau tidaknya keluhan muskuloskeletal.

Berdasarkan hasil penyebaran kusioner Nordic Body Map (NBM) diketahui bahwa responden/pekerja merasa sakit setelah bekerja pada pergelangan tangan kiri sebesar $42 \%$. Responden merasakan agak sakit setelah bekerja beberapa anggota tubuh antara lain; pada bagian pergelangan tangan kanan sebesar $58 \%$ dan pada tangan kanan sebesar $58 \%$. Sedangkan bagian tubuh lain merasakan agak sakit sebesar $42 \%$ antara lain: Sakit di bahu kanan, Sakit pada pinggang, Sakit pada lengan bawah kiri, Sakit pada tangan kiri, Sakit pada betis kanan, Sakit pada pergelangan kaki kiri, Sakit pada pergelangan kaki kanan, Sakit pada kaki kanan. Untuk bagian tubuh yang lain prosentasi $<40 \%$.

Sedangkan hasil kusioner QEC menunjukkan bahwa skor dari 4 orang pekerja yaitu 178, 148, 151 dan 134. Empat pekerja yang memiliki skor tinggi berada pada bagian molen/pengadukan bahan, operator oven basah. Skor tersebut berada pada Action level 4. Total skor melebihi 123, menunjukkan postur tersebut berbahaya dan harus dilakukan investigasi lebih lanjut dan dilakukan penanganan secepatnya. 
Sedangkan hasil skor dari 8 orang pekerja yaitu 97, 101, 104, 105, 106, 108, 116 dan 123. Skor tersebut berada pada Action level 3 sehingga perlu investigasi lebih lanjut dan dilakukan penanganan dalam waktu dekat. Hasil skor dari 3 orang pekerja yaitu 75, 87, 87 dan 83. Skor tersebut berada pada Action level 2 perlu investigasi lebih lanjut. Sedangkan 4 pekerja memiliki skor $<70$ yang berarti nilai dapat diterima yaitu $60,60,60,64$.

Berdasar analisis dengan menggunakan metode HAZOP, NBM dan QEC maka selanjutnya dilakukan perancangan rekomendasi atau usulan perbaikan terhadap potensi bahaya yang muncul. Namun untuk pelaksanaannya bisa dipriorotaskan sesuai tingkat resiko paling tinggi. Berikut usulan perbaikan yang diberikan berdasar potensi bahaya yang ada antara lain:

a. Sikap pekerja, usulan perbaikan yang diberikan yaitu perlu adanya pelatihan K3 tentang penggunaan alat pelindung diri untuk meminimalisir potensi bahaya yang ada, membuat worksheet dalam penggunaan APD dan menempelnya di area kerja sehingga pekerja bisa membaca dan antar pekerja bisa saling mengingatkan dan perlu adanya tindakan berupa teguran atau sanksi bagi yang melanggar.

b. Kondisi lingkungan kerja fisik, usulan perbaikan yang diberikan yaitu dengan membersihkan area kerja setelah selesai bekerja, memberikan kipas angin untuk mengurangi temperatur ruang yang panas, menyediakan APD sepeti masker, earplug.

c. Tumpahan tepung dan adonan kerupuk, usulan perbaikan yang diberikan yaitu dengan membersihkan bekas tumpahan yang tercecer di lantai setiap selesai proses, membuat peraturan prosedur proses produksi yang baik.

\section{KESIMPULAN} berikut:

Kesimpulan yang dapat diambil pada penelitian ini berdasar rumusan masalah adalah sebagai

a. Hasil analisis potensi bahaya menggunakan metode HAZOP diketahui bahwa sumber bahaya yang dapat atau berpotensi menimbulkan kecelakaan kerja adalah sikap pekerja, kondisi lingkungan kerja fisik, lantai licin karena adanya tumpahan tepung terigu dan adonan bahan pembuatan kerupuk.

b. Hasil analisis menggunakan konsep ergonomi dengan menggunakan kuisioner NBM dan QEC diketahui bahwa terdapat resiko ergonomi yang dalam pekerjaan proses pembuatan kerupuk. Resiko yang dialami berupa gangguan muskuloskeletal dan kelelahan yang muncul pada bagian punggung, pinggang, lengan, pergelangan tangan, betis dan pergelangan kaki.

\section{UCAPAN TERIMA KASIH}

Ucapan terima kasih yang tak terhingga kepada Universitas Widya Mataram melalui LPPM yang telah memberikan pendanaan selama penelitian berlangsung.

\section{DAFTAR PUSTAKA}

[1] Aprianto, H. 2012. “Analisis Faktor Penyebab Cumulative Trauma Disorders menggunakan metode Quick Exposure Checklist Pada Profesi Penjahit”. E-Jurnal Teknologi Industri. Universitas Gunadarma, Depok.

[2] Pujiono, B. N., Tama, I. P., \& Efranto, R. Y. 2013. "Analisis Potensi Bahaya Serta Rekomendasi Perbaikan Dengan Metode Hazard and Operability Study (HAZOP) Melalui Perangkingan OHS Risk Assessment and Control (Studi Kasus: Area PM-1 PT. Ekamas Fortuna)". Jurnal Rekayasa dan Manajemen Sistem Industri, 1. 2, 253-263.

[3] Pratama. P., Tannady, H., Nurprihatin, F., Ariyono, H.S., Sari, S.M. 2018. "Identifikasi Risiko Ergonomi Dengan Metode Quick Exposure Check dan Nordic Body Map". Jurnal PASTI, XI. 1, 13-21.

[4] Retnowati, D. 2017. "Analisa Resiko K3 dengan Pendekatan HAZARD and Operability Study (HAZOP)". Engineering and Sains Journal, 1. 1, 41-46.

[5] Suyono, K.Z., Nawawinetu, E.D. 2013. "Hubungan antara Faktor Pembentuk Budaya Keselamatan Kerja dengan Safety Behavior di PT. DOK dan Perkapalan Surabaya Unit Hull Constraction”. The Indonesian Journal of Occupational Safety and Health, 2. 1, 67-74.

[6] Tarwaka. (2017). Keselamatan dan Kesehatan Kerja Manajemen Dan Implementasi K3 di Tempat Kerja. Surakarta: Harapan Press. 